\title{
Relationship among Level of Participation of Diversity Engagement Activities, Perceived Campus Climate, Meaningful Interaction and Sense of Civic Responsibility of Undergraduate Students in Malaysia
}

\author{
Loh Yit Phing ${ }^{1}$, Jusang Bolong ${ }^{2}$, Moniza Waheed ${ }^{3}$, Akmar Hayati Binti Ahmad Ghazali ${ }^{4}$ \\ Faculty of Modern Languages and Communication, Universiti Putra Malaysia, Malaysia 1,2,3,4
}

\{lyitphing@gmail.com\}

\begin{abstract}
Twenty-first century is an increasingly diverse society and interdependent global community. Due to changing demographics in higher education and increasing demands of the educative value of diversity in need, "twenty-first-century college student diversity outcomes" is a term used to describe the skills necessary for college graduates to function in the diverse world. This study is to examine the relationship between the level of participation in curricular diversity engagement activity, co-curricular diversity engagement activity, level of campus climate, and level of participation in meaningful interaction with a sense of civic responsibility. It also tested the level of meaningful interaction as a moderator between the relationship of level of participation in curricular, co-curricular and civic responsibility among students. This study was adopting purposive sampling, 1.420 respondents of different ethnicities at six Malaysia universities involved. Survey through selfadministered questionnaires was used in this study. Social Package for the Social Sciences (SPSS) and Structured Equation Modelling (SEM) with Partial Least Squares (PLS) used for analysis. The findings provided useful information to better understanding regarding the level of participation of students in diversity engagement activity and their sense of civic responsibility. This findings also could be used by the university to enhanced curricular and cocurricular diversity engagement activity and campus climate that support diversity.
\end{abstract}

Keywords: diversity; curricular; co-curricular; campus climate; civic responsibility

\section{Introduction}

In an education context, the university has a role to play to prepare the undergraduates to be a well-rounded citizen. There are many studies shown that diversity engagement in university brings many positive outcomes. There are many researches on how diversity affects undergraduate students. Researches used theoretical frameworks grounded in psychology to explain the process where students from racially and socially homogenous pre-college 
environment interact with diverse others. Gurin et al. shown that this challenge students' notions of their diverse peers [1].

Twenty-first century college student diversity outcomes is a term used to describe the skills necessary for undergraduates to function in an increasingly diverse society and interdependent global community, including being able to interact with diverse others and democratic and civic engagement abilities $[1,2,3,4]$. Several studies $[3,5,6]$ have documented the educational value of diversity for both cognitive and social outcomes. Research is needed to look into the educative value of diversity due to the changing demographics in higher education and globalization. Research on diversity engagement and educational value of diversity must be context-specific, including institutional type, state, and region [7].

This study is instrumental because it is examining the relationship between civic responsibility and diversity engagement which focus on multiethnic Malaysians in the context of education. In the past, some studies investigating civic outcome from the education perspective. Scholar rarely did the concept of examining diversity engagement's influence on civic outcome in Malaysia context. There are some studies $[8,9,10,11,12]$ on civic responsibility from cultural-related diversity engagement and peer civic talk among final year undergraduates. However, in the study, the scholar did not use meaningful interaction as a moderator. Instead, it was used as a variable to test direct relationship with civic responsibility. Besides, the campus climate not included as a variable in the study.

\section{Method}

This study is a quantitative research whereby the unit of analysis is at the individual level. There are six (6) universities which are Universiti Putra Malaysia (UPM), Universiti Kebangsaan Malaysia (UKM), Universiti Tenaga Nasional (UNITEN), Universiti Malaya (UM), Universiti Sains Malaysia (USM) and Universiti Teknologi Malaysia (UTM) participated in this study. There are two types of variables used in this study which are the independent variable and dependent variable. There are three (3) independent variables and one (1) dependent variables which used to meet the research objectives. Besides, a moderating variable is also introduced to examine the effect of the independent variable on the dependent variables. This study is using hypotheses testing to explain the nature of the relationship between independent variables and dependent variables. It offers an enhanced understanding of the relationship between variables.

Data collected via self-administered survey within eighteen (18) months. This study is a one-shot study where the data to answer all the research questions is gathered just once for a specified period. This study is to find out the relationship among the variables, so it is the best approach to run this study. To test the research model, the questionnaire has five (5) latent constructs that form the exogenous (independent) and endogenous (dependent) constructs. All items adapted from past studies.

The framework consists of three (3) exogenous constructs that form the structure of the framework, which consist of the level of participation of curricular activities, co-curricular activities, and campus climate. The level of participation of curricular activities is operationalized by eight (8) indicators which are adopted and adapted from [5]. The second variable is the level of participation in co-curricular activities. This variable seeks the respondents' perception of their level of participation in co-curricular activities. This variable consist of seven (7) items adapted from [5]. The third variable is the perception of campus climate. There are eleven (11) items used to measure campus climate. The endogenous 
(dependent) variable is the perceived sense of civic responsibility. There are nine (9) items for this construct. The last variable is the moderator variable which is the level of meaningful interaction. There are ten (10) items used for this variable.

\section{Result and Discussion}

This section presents descriptive data and frequencies of respondents. A total of 1420 respondents participated in this study; only 1240 respondents were valid for the analysis. There were more female, representing $51.9 \%$ of the respondents. Male respondents were making up $48.1 \%$ of the total sample. This figure corresponds with the gender ratio of the total population of students at HEIs in Malaysia, where female students make up of $60 \%$, and male students make up of $40 \%$ of the overall population. More than half of the respondents $(59.9 \%)$ were Malays, and $18.9 \%$ were Chinese. The rest comprised of Indians $16.9 \%$, and others $4.7 \%$. More than half of the respondents, $50.5 \%$ were in the age group of $24-26(\mathrm{M}=23.72$, $\mathrm{SD}=1.37$ ), suggested that most of them were in their final year of study. The number of respondents in the six locations has a slightly different number. University Sains Malaysia has a slightly higher number of respondents $(\mathrm{n}=244)$.

\section{H1: Level of participation of curricular diversity engagement activity is significantly and positively related to civic responsibility.}

The first hypothesis for this study is regarding the level of participation of curricular diversity engagement activities and civic responsibility. With the t-value showing no significant relationship ( $\beta=0.005, \mathrm{t}$-value 0.169 ), thus we can conclude that level of participation of curricular diversity engagement activity has no relationship with civic responsibility and $\mathrm{H} 1$ was not supported. This finding found that curricular initiatives that support racial or ethnic diversity shown a gap in campus. The finding showed that campus needs to develop a much-appreciated program for a multicultural society amongst students and faculty.

\section{H2: Level of participation in co-curricular diversity engagement activity is significantly and positively related to civic responsibility.}

The second hypothesis for this study is regarding the level of participation of co-curricular diversity engagement activity and civic responsibility. With the beta value showing a positive relationship ( $\beta=0.112$, t-value 3.722), thus we can conclude that level of participation of cocurricular diversity engagement activity has significant relationship with civic responsibility and $\mathrm{H} 2$ was supported. Like other research, this study showed that co-curricular activities report significant in their programs that support diversity.

\section{H3: Level of campus climate is significantly and positively related to civic responsibility.}

The third hypothesis for this study is regarding the level of campus climate and civic responsibility. With the beta value showing a positive relationship, $(\beta=0.170$, t-value 5.685), thus we can conclude that the level of campus climate has significant relationship with civic responsibility and $\mathrm{H} 3$ was supported. The finding shown that more institutions articulate the 
value of diversity, commit to diversity issues and support for creating a diverse learning environment is significant to enhance sense of civic responsibility among students.

\section{H4: Level of participation in meaningful interaction is significantly and positively related to civic responsibility.}

The fourth hypothesis for this study is regarding the level of participation of meaningful interaction and civic responsibility. With the beta value showing a positive relationship, $(\beta=$ 0.059 , t-value 2.102 ), thus we can conclude that level of participation of meaningful interaction has significant relationship with civic responsibility and H4 was supported. Meaningful interaction can enhance understanding among racial and ethnicity and make campus climate-friendly for diverse students. Allport's 1954 contact hypothesis states that interactions across racial and ethnic boundaries can facilitate mutual liking and respect under certain conditions. Using this assumption, colleges and universities often attempt to foster interactions across difference to promote several outcomes, including reduction of racial tension. Hence lead to better multicultural competencies.

H5: Level of participation in meaningful interaction moderates the relationship of level of participation in curricular diversity engagement activity and civic responsibility.

The positive relationship between the level of participation in curricular diversity engagement activity and level of civic responsibility will be stronger when the undergraduate has a better level of meaningful interaction. Result indicates the overall results for hypothesis testing and the result for the moderating effect of the level of meaningful interaction. For H5, with the $\beta=0.75$, t-value 2.302, thus this indicates that the study finds a significant relationship between these variables. Hence there is a moderating effect of level of participation in meaningful interaction on the relationship between level of participation in curricular diversity engagement activity and level of civic responsibility. H5 was supported. The finding found that the level of participation in meaningful interaction with diverse others was essential for curricular. It makes clear on the relationships between student interactions and curricular. As in the finding in H1, level of participation in curricular diversity engagement activity alone was not significant. The finding showed that curricular alone is not sufficient to bring a better outcome of civic responsibility. H5's finding is in line with (Laird et al., 2005) Nelson-Laird, Engberg, and Hurtado's examination of the importance of support for racial diversity through the formal curriculum and activities outside of the formal classroom.

H6: Level of participation in meaningful interaction moderates the relationship of level of participation in co-curricular diversity engagement activity and civic responsibility.

The positive relationship between the level of participation in co-curricular diversity engagement activity and level of civic responsibility will be stronger when the undergraduate has a better level of meaningful interaction. For H6, with the $\beta=0.006$, t-value 0.182 , thus this indicates that the study finds no significant relationship between these variables. Hence there is no moderating effect of level of participation in meaningful interaction on the relationship between level of participation in co-curricular diversity engagement activity and level of civic responsibility. H6 was not supported. 
One possible explanation is that, according to Guri et al., 2002, emphasis on the importance of substantive and meaningful interactions with diverse peers in college. For example, students in culturally themed residential programs regularly engaged with diversity in a co-curricular setting. They may receive a more significant benefit from interactions with racially or ethnically different peers. By contrast, students who attend a one-time campus workshop or discussion on race may receive fewer educational benefit from interacting with their diverse peers because their interactions not sustained over time.

\section{Discussion}

In Allport's contact hypothesis, two conditions are necessary for positive intergroup contact. Firstly is equal-status condition. The second condition is to provide students with the opportunity to develop shared goals through program initiate by colleges [13]. This may be difficult for campuses to achieve as there are social and economic disparities among ethnic groups. When interaction did not meet the conditions, it is challenging to build mutual liking and respect in interaction. The quality of interactions among students with diverse peers and degreed of intergroup anxiety have with particular racial groups are becoming more critical [1]. This might be the possible explanation of why meaningful interaction did not moderate the relationship between co-curricular diversity engagement and sense of civic responsibility.

Another point worth considering is that the existing University and University Colleges Acts (UUCA) might have limit ordinary students interest in actively talking about social and political affairs of society and country. This provision under section 15(a) of the act prohibits undergraduate students and student organizations from actively express, support or participate in any political organization and from playing a vital part in the socio-political life of our nation with the expressed permission of the Vice-Chancellor. It is motivating to know that the current Education Minister Dr Maszlee tabled changes to the UUCA Educational Institutions (Discipline) Act 1976, and the Private Higher Educational Institutions Act 1996 in the Dewan Rakyat last year December to drop the act and provide more freedom of association to university students.

Based on the above discussion, it can conclude that all variables, curricular and cocurricular diversity engagement, campus climate and meaningful interaction are significant variables that contribute to a sense of civic responsibility. Although curricular diversity did not have a direct relationship with civic responsibility, it found significant when the moderator meaningful interaction was add-in. Next, for meaningful interaction as a moderator to influence the relationship of curricular and co-curricular diversity engagement, it has to be significant to manifest its role. We can conclude that the level of meaningful interaction among students is not sufficient because it did not moderate the relationship between cocurricular diversity engagement and civic responsibility.

\section{Conclusion}

It is crucial to understand how campus continues to support diversity in education so that students are prepared to function in the new era of global interdependence. Higher education institutions play a role in this dynamic sociopolitical environment as the shift from focusing on equal access [14], and it has changed to redefining merit. The discourse on race and ethnicity in higher education has been focused on diversity as central of research in other research. Often diversity refers to race and ethnicity. However, it has expanded to understanding of 
gender, sexual orientation, and class heterogeneity.There is urgency for the institution to prepare students for the diverse world in which they will work. Students must be ready to work in a multilingual environment, culturally diverse individuals in various setting. For students coming from homogeneity background, college is an excellent platform for them to learn how to interact with diverse others effectively.

\section{References}

[1] P. Guri, E.L. Dey, S. Hurtado, G. Gurin, G. "Theory and Impact on Educational Outcomes." Harvard Educational Review, Vol. 72 No. 3, pp. 330-366, 2002.

[2] M.J. Chang, A.W. Astin, D. Kim, D. (2004). "Cross-racial interaction among undergraduates: Some consequences, causes, and patterns." Research in Higher Education, Vol. 45, No. 5, pp. 529-553, 2004.

[3] S. Hurtado, S. (2007). "Linking Diversity with the Educational and Civic Missions of Higher Education." The Review of Higher Education, Vol. 30, No. 2, pp. 185-196, 2007.

[4] V.B. Saenz, H.N. Ngai, S. Hurtado. "Factors Influencing Positive Interactions Across Race for African American, Asian American, Latino, and White College Students." Research In Higher Education, Vol. 48, No. 1, pp. 1-38, 2007.

[5] P. Gurin, B. Nagda (2006). "Getting to the what, how, and why of diversity on campus." Educational Researcher, Vol. 35, No. 1, pp. 20-24, 2006.

[6] T.F.N. Laird, M.E. Engberg, S. Hurtado, S. "Modelling Accentuation Effects: Enrolling in a Diversity Course and the Importance of Social Action Engagement." The Journal of Higher Education, Vol. 76, No. 4, pp. 448-476, 2005.

[7] E. Bash. Institutional commitment to policies and practices that support racial and ethnic diversity in the post-affirmative action era: examining sense of belonging and diversity engagement. PhD Proposal, 2015. Retreived from: https://doi.org/10.1017/CBO9781107415324.004

[8] S. Ahrari, B. Abu, B. Hassan, N. Wahiza, A. Wahat, Z. Zaremohzzabieh, Z. "Deepening critical thinking skills through civic engagement in Malaysian higher education." Thinking Skills and Creativity, No. 22, pp. 121-128, 2016.

[9] S. Ahrari, J. Bt. Othman, Md. S. Hassan, B.A. Samah, Z Zaremohzzabieh. "Using Network-Based Theory to Develop a Curriculum for Citizenship Education in Higher Institutions." Social Indicators Research, Vol. 130, No. 3, pp. 1207-1228.

[10] P.L. Ong, S. Selvadurai, P.H. Ong, M.A.A.M. Najib. "EDUCATION FOR SOCIAL COHESION : PROMOTING 1R + 3R," e-Bangi, Vol. 11, No. 2, pp. 18-20, 2016.

[11] P.L. Ong, S. Selvadurai, B. Saibeh, M.M. Radzi, S.A. Hamzah. Tracking the Pathways of Education in Malaysia : Roots and Routes." Asian Social Science, Vol. 9, No. 10, pp. $1-13,2017$.

[12] E. Tamam, A.N. Abdullah. "Influence of ethnic-related diversity experiences on intercultural sensitivity of students at a public university in Malaysia." Asia Pacific Education Review, Vol. 13, No. 3, pp. 519-528, 2012.

[13] B. Nagda, X. Zúñiga. "Fostering meaningful racial engagement through intergroup dialogues." Group Processes \& Intergroup Relations, Vol. 6, No. 1, pp. 111-128, 2003.

[14] C.N. Fulford. Preparing Students to Work in a Globally Diverse World: The Relationship of College Students' Backgrounds and College Experiences to Their 
Orientation toward Diversity. Dissertation. Bowling Green State University, Ohio. 2009. 